\title{
Elifaz, Baldade, Sofar e Eliú: quatro teólogos e um só destino
}

\author{
Eliphaz, Bildad, Zophar and Elihú: \\ four theologians and one destiny
}

Luiz Alexandre Solano Rossi

\section{Resumo}

O livro de Jó é composto a partir de vários discursos os quais podem ser divididos em dois grupos. O primeiro seria os discursos de Jó e o segundo os discursos de seus amigos. Mais do que personagens reais, todos os personagens se apresentam como personificações teológicas. Os amigos tentam convencer Jó de que sua dramática experiência de vida é resultado de um pecado contra Deus. Todos eles falam a partir da teologia oficial e se negam a olhar para o real sofrimento de Jó a fim de consolá-lo. Os discursos dos amigos de Jó são uma armadilha de palavras e, por isso, irreconciliáveis com a teologia que nasce da experiência dramática de Jó.

Palavras-chave: Teologia. Livro de Jó. Discurso. Drama.

\section{Abstract}

The book of Job is made up of various discourses and can be divided into two groups. The first would be Job's speeches and the second would be his friends' speeches. More than real characters, all characters present themselves as theological personifications. Friends try to convince Job that his dramatic life experience is the result of a sin against God. They all speak from official theology and refuse to look at Job's real suffering in order to comfort him. The discourses of Job's friends are a trap of words 
and therefore irreconcilable with the theology that comes from Job's dramatic experience.

Keywords: Theology. Book of Job. Speech. Drama.

\section{Introdução}

$\mathrm{O}$ artigo tem como objetivo uma aproximação bíblico-teológica dos discursos dos amigos de Jó. Todos eles, sem exceção, verbalizam uma teologia que procura convencer que a realidade trágica vivida por Jó seria uma clara consequência de seus presumidos pecados. Quatro amigos e quatro discursos que fazem o mesmo caminho. Todos pertencem à mesma escola teológica e, por isso, poderíamos dizer que tanto os discursos de Jó, quanto os discursos dos amigos, representam personificações teológicas irreconciliáveis.

Os amigos estão decididos a encontrar em Jó alguma situação de pecado e que cause nele um grande e real desconforto. A preocupação em defender seus próprios interesses não lhes permite deixarem-se questionar pelas dramáticas experiências de Jó. O Deus descrito pelos discursos dos amigos não corresponde ao Deus que Jó conhece e que parece estar cada vez mais ligado.

Se os amigos elaboram uma cilada teológica para Jó, ele, ousadamente, aplicará aos injustos a descrição da felicidade do justo, invertendo a lógica daqueles. Jó, provavelmente, a partir de sua experiência de sofrimento, denuncia com veemência uma sociedade onde as vítimas da opressão são excluídas com a justificativa teológica de uma presumida culpa deles. A vítima jamais tem culpa e, principalmente, culpa teológica.

No livro de Jó encontramos grandes discursos colocados nos lábios de 5 personagens: Jó, Elifaz, Bildad, Sofar e Eliú. Para efeito comparativo, os discursos de Jó somam 20 capítulos (513 versos), os discursos dos amigos estão assim distribuídos: Elifaz com 4 capítulos (113 versos); Bildad com 3 capítulos (49 versos); Sofar com 2 capítulos (49 versos) e Eliú com 6 capítulos (165 versos).

Em meio a tantas palavras, é sintomático que Jó considerava seus amigos e o conjunto de suas palavras teológicas como "consoladores inconvenientes" $(16,2)$ ou, em forma de pergunta: "Por que me consolam em vão?" $(21,34)$. Se os amigos, arrogantemente, diziam que as consolações 
que eles traziam deveriam ser consideradas por Jó como "consolações divinas"; Pope sugere que os sujeitos dos discursos "esfregam sal nas feridas abertas". ${ }^{1}$

No encontro das palavras de cada um deles se perceberá que as palavras de Jó estão em clara oposição ao conforto que seus amigos procuravam conceder a ele.

\section{A teologia de um Deus comerciante}

O primeiro dos discursos é proferido por Elifaz, muito provavelmente, o líder do grupo de amigos. Os discursos dele trazem todos os motivos, temas e argumentos que serão retomados, aprofundados e desenvolvidos nos discursos subsequentes de seus amigos. ${ }^{2}$ Por meio de sua moral utilitária, Elifaz, "o apóstolo da moral utilitária", termo consagrado por Ternay, ${ }^{3}$ vai apresentar e representar a teologia oficial da retribuição. Ele afirma com insistência o dogma da justiça retributiva. Pixley, interpretando o texto, salienta que para Elifaz "o injusto sofre uma má sorte". ${ }^{4}$

A lógica com a qual Elifaz trabalha é algo irrefutável para ele: aqueles que semeiam e cultivam miséria e injustiça colherão exatamente o que foi semeado e cultivado. A lógica é precisa porque faz analogia com o mundo do campo. E, na natureza, colhe-se exatamente o tipo de semente jogada sobre a terra. Ninguém jamais esperaria colher algo diferente daquilo que havia semeado. Assim, os semeadores de miséria e injustiça certamente perecerão e serão consumidos pelo sopro de Deus. Elifaz consegue levar seu discurso teológico da retribuição a um nível possivelmente jamais alcançado. Um discurso que atinge ares de absoluto e, portanto, dogmático: "Deus sopra, e eles perecem; o sopro de sua ira os consome. Embora o leão ruja e o leopardo também, os dentes dos filhotes são quebrados: sem a presa, o leão acaba morrendo, e as crias da leoa debandam" (Jó 4,9-11). A armadilha de palavras teológicas estava posta e não havia modo de escapar. Mas, lembremos, que os conteúdos do discurso de Elifaz são um reflexo dos conhecimentos que ele já havia introjetado em sua mente e, dessa forma, era como se fosse uma segunda pele. Ele fazia o discurso teológico "como se", ou seja, como se fosse Deus ou

\footnotetext{
${ }^{1}$ POPE, M., Job, p. 122.

${ }^{2}$ SCHÖNBERGER, L. S., Um caminho através do sofrimento.

${ }^{3}$ TERMAY, H., O livro de Jó, p. 53.

${ }^{4}$ PIXLEY, J., El libro de Job, p. 83.
} 
representante de Deus. E, na verdade, as palavras dele jamais convenceram a Jó e muito menos a Deus.

Em 5,16-17, Elifaz interpreta o sofrimento de Jó como se fosse correção de Deus: "Veja: feliz o homem a quem Deus corrige. Por isso não despreze a lição de Shadai. Pois é ele quem causa a dor e cuida do ferimento, é ele quem fere e cura com sua própria mão". O sofrimento de Jó não seria o resultado da ação de seus inimigos (como geralmente acontece nos salmos de súplica), mas por causa de alguma ação pecaminosa que ele não consegue identificar. A consequência desse tipo de teologia poderia ser vista como sinal do amor de Deus, isto é, todo aquele que estivesse passando por experiências contraditórias e doloridas, poderia se considerar como um bem-aventurado. Pixley ${ }^{5}$ segue a mesma compreensão ao afirmar que Elifaz interpreta o sofrimento como se fosse uma correção de Deus. Para Elifaz e sua teologia, Jó não precisa se sentir desmotivado, perdido e sem esperança a ponto de maldizer seu nascimento. Para Elifaz, trata-se de uma teologia que se fundamenta na tentativa de convencer Jó de sua culpa, afirmando que Deus é o grande e único causador de seu sofrimento. Trata-se do que Schonberger denomina de "pedagogia divina do sofrimento". ${ }^{6}$

Nos discursos de Elifaz encontramos uma anulação da força virulenta daqueles que exercem poder, seja ele político ou econômico. Seria temerário afirmar que no livro de Jó não existam inimigos que causam o sofrimento através de atos de violência. E, sem sombra de dúvida, de sofrimento e de violência concretos e que podiam ser nominados especificamente como os profetas clássicos faziam quando os denominavam de chefes políticos, militares, reis, filhos do rei, rainha, arrecadadores de impostos, usurários, senhoras nobres, sacerdotes, falsos profetas, latifundiários, juízes, ministros do rei. Em Jó os atos de violência são revertidos unicamente contra os pobres (Jó 24,2-4), deixando-os numa condição em que a própria existência era colocada em risco. Uma pergunta que deriva dessa reflexão se faz necessária: não há como contestar que o ser humano vive nos limites do que é provisório e limitado. No entanto, por que milhares de pessoas são condenadas dia após dia a morrer antes da hora? Uma possível resposta deveria nos inserir no campo da responsabilidade pública da teologia?

A partir de suas concepções tradicionais e em sua defesa, Elifaz abandona

\footnotetext{
${ }^{5}$ PIXLEY, J., El libro de Job.

${ }^{6}$ SCHONBERGER, L. S., Um caminho através do sofrimento, p. 34.
} 
o sofrimento concreto de Jó. Não há espaço para ambas as ações, ou seja, defender a verdade de suas tradições e cuidar do próximo que sofre. A pergunta de fundo que emerge dessa situação poderia ser assim formulada: religião ou a vida, quem tem a preferência? Ao fazer a opção pela religião e deixar a vida tangencialmente, a religião se metamorfoseia em um instrumento que ao invés de defender, produz a morte. Os discursos de Elifaz e de seus amigos nos mostram que eles caíram nessa armadilha. $\mathrm{O}$ argumento teológico dele era por demais dogmático: o sofrimento do injusto é uma decorrência da prática de sua maldade. Por isso, em vários momentos, Elifaz procurará refutar as expressões de Jó quando dizia que Deus tratava igualmente o injusto quanto o inocente. Se Jó apelava para sua experiência direta, Elifaz caminhava levando consigo a autoridade de muitas gerações de sábios. E, para chegar aos seus objetivos, estava disposto a encaminhar o caso de Jó sem investigá-lo, com o fim único de defender a ordem ideológica e teológica refinada pelos anos. Para isso, Elifaz precisa apresentar Jó com características que comprovem sua tese. Dessa forma, ele distorce a realidade e apresenta Jó como sendo uma pessoa injusta, rebelde e ímpia. Possivelmente, a realidade se encontrava distorcida porque a distorção causada pelo caos interior já se encontrava estabelecida. Pixley $^{7}$ e Ternay ${ }^{8}$ enfatizam que "é impressionante ver como ele não diz uma só palavra sobre a aflição de Jó. Vê-se como a preocupação da doutrina pode abafar qualquer forma de compaixão".

O objetivo de Elifaz, em seu primeiro discurso, é o de substituir os conteúdos teológicos da mente de Jó por uma doutrina tradicional. Rigorosamente preso a esse objetivo, em nenhum momento há qualquer manifestação de preocupação com a experiência de sofrimento de Jó. Não se preocupa e também não se deixa interpelar pela força do sofrimento do amigo. Todavia, não é somente Elifaz, também os demais amigos não dizem uma só palavra a respeito do sofrimento de Jó. Uma das mais impressionantes questões da teologia ele não consegue compreender, ou seja, toda teologia deve ser refletida como ato segundo para que a vida possa ser compreendida como ato primeiro. Nesse sentido, a teologia nasce pública e com a missão de defender a vida, principalmente a vida dos vulneráveis. O que de fato certifica a ação teológica é a reflexão sobre o ser humano em seu ambiente concreto. A reflexão, portanto, a partir de lugares abstratos, poderia levar o sujeito a adotar

\footnotetext{
${ }^{7}$ PIXLEY, J., El libro de Job.

${ }^{8}$ TERNAY, H., O livro de Jó, p. 109
} 
métodos teológicos cujo único objetivo seria a coisificação do ser humano e, de forma consequente, sua manipulação.

O método teológico de Elifaz pode ser considerado o da "visão noturna" (Jó 4,12-21). Alonso Schökel ${ }^{9}$ salienta que a revelação possui um papel central na construção de conteúdo do discurso de Elifaz e conclui que ele "aparece prisioneiro de seus esquemas mentais (...) sua ortodoxia simplista não permite que veja as coisas evidentes e, assim, apela para o 'que viu'”. No entanto, ele se encontra muito distante das características de um profeta. Enquanto Elifaz produz o conteúdo de seus discursos alienado da realidade - em sonhos os profetas procuravam fazer teologia desde o chão da história. Ao buscar nos sonhos os ingredientes de seu discurso teológico, Elifaz não conseguirá olhar para a história que passa diante de seus olhos e interpretá-la bem como interpelá-la.

De acordo com Rossi:

Elifaz apresenta um Deus de uma religião demasiadamente alienante que abençoa todos aqueles que não questionam a sua atuação. Encontramos aqui o funcionamento da teologia da retribuição como testemunha de uma religião mercantil. Esta maneira de pensar faz de Deus um negociante. E, numa espiritualidade mercantil, o ouro nunca deixa de ter importância. ${ }^{10}$

E Ternay assim resumirá a perspectiva do discurso de Elifaz:

Elifaz condena o seu "amigo", sem deixar-lhe o tempo para se exprimir: "De toda maneira, disse para Jó, é melhor que o saibas, isso não te servirá para nada...podes gritar quanto quiseres...ninguém vai te escutar". Desde o início, a posição que o primeiro interlocutor de Jó adotou já deu uma boa orientação do gênero de argumentação que ele deveria suportar. ${ }^{11}$

\section{Teologia como linha de produção: pensar é proibido}

Se Elifaz vive de revelação, o segundo amigo a se apresentar defende a hipótese de se viver tão somente a partir da tradição e que impossibilitaria a capacidade de pensar. Afinal, para que pensar se a tradição já respondeu todas

\footnotetext{
${ }_{9}^{9}$ ALONSO SCHÖKEL, L.; SICRE DIAZ, J. L., Job, p. 168.

${ }^{10}$ ROSSI, L. A. S., A origem do sofrimento do pobre, p. 47.

${ }^{11}$ TERNAY, H., O livro de Jó, p. 98.
} 
as perguntas que possam ser feitas? Para Baldad pensar é definitivamente proibido. Ele apresenta uma nova forma de totalitarismo que vai além da ordem política e econômica. Estamos ao redor de uma forma de totalitarismo que cria sistemas teológicos que dão voltas ao redor de si mesmos, estabelecendo o fundamentalismo como premissa básica de seu fundamento.

Segundo Rossi o discurso teológico de Baldad apresenta três possíveis enfoques, a saber:

a) a tradição a que ele se reporta tinha por ato intocável que o castigo dos ímpios e a proteção do justo eram uma lei divina tão firme e segura como a lei de causa e efeito na física; b) a irretocabilidade da tradição dos ancestrais; c) a omissão de se pensar por conta própria e passar a repetir constantemente, o que se aprendeu com a tradição dos ancestrais. Uma possível conclusão é esperada: para Baldad, o dogma da retribuição jamais poderia ser distorcido e/ou negado nem pelos homens e muito menos pelo próprio Deus. ${ }^{12}$

Se Elifaz era enérgico, Baldad ao assumir a palavra se mostra exasperado. Era incompreensível para ele que Jó falasse continuasse após a brilhante exposição teológica de Elifaz (Jó 8,2): "até quando você, Jó, vai falar assim? Até quando suas palavras serão como um forte vento?". E quando Baldad se dispõe a falar é que percebemos que a teologia dele é a mesma de seu predecessor. Ele afirma que o sofrimento de Jó é em decorrência do pecado de seus filhos. Jamais palavras teológicas machucaram tanto, vejamos: "Se os seus filhos pecaram contra Deus, ele já os entregou ao poder dos próprios crimes" (Jó 8,4). E continua afirmando que a única solução a disposição de Jó seria a de que ele orasse a Deus e pedisse perdão pelos pecados cometidos, mostrando, dessa forma, que realmente estava arrependido: "e, se você se conservar puro e reto, ele cuidará de você e o restaurará na tua legítima prosperidade" (Jó 8,6). Uma ponta de ironia transparece no discurso de Baldad, ou seja, Jó jamais pediu que sua prosperidade fosse restituída! Os amigos de Jó estavam presos numa teia de aranha e quanto mais se mexessem ou falassem, mais se tornariam presos. Baldad pensa somente na teologia do sucesso e da prosperidade: "Sua situação anterior parecerá coisa pequena em comparação com a grandeza do seu futuro" (Jó 8,7). O discurso teológico de Baldad não traz novidade alguma, isto é, o justo não sofre: "Por acaso,

${ }^{12}$ ROSSI, L. A. S., A falsa religião e a amizade enganadora, p. 58-59. 
brota o papiro fora do pântano? Ou pode o junco crescer sem água? [...] Tal é o destino de quem se esquece de Deus, e assim desaparece a esperança do injusto" (Jó 8,11 e 13).

Ao atribuir a morte dos filhos aos pecados do próprio Jó, Baldad mostra quão desesperado se encontra. Jó havia errado e precisava consertar a situação através de incontáveis súplicas a Deus e jamais tentando discutir com ele. $\mathrm{Na}$ literatura bíblica o profeta Ezequiel $(18,1-9)$ já havia abordado e resolvido o problema da culpa individual ou coletiva. $\mathrm{O}$ orientalista Liverani assim explica a responsabilidade coletiva em Israel e no antigo oriente Próximo:

Assegura que no antigo Oriente Próximo, e em Israel em particular, a responsabilidade coletiva possuía dois campos de aplicação, um "horizontal" e um "vertical". A responsabilidade coletiva "horizontal" é a que tornava responsáveis por um delito não somente os autores individualmente considerados, mas também suas famílias e as comunidades locais (vilas, cidades). Assim sendo, quando o responsável não era identificado, a comunidade à que pertencia (que evidentemente o protegeu) devia necessariamente assumir o ônus da culpa: se os mercadores do rei de Ugarit são mortos na terra de Karkemish... e os seus matadores não são presos, os filhos de Karkemish irão a Ugarit e declararão sob juramento: "Não sabemos quem são os assassinos, e os bens dos mercadores desapareceram". ${ }^{13}$

E Rossi, por sua vez, enfatiza que o processo de responsabilidade coletiva ressoa também na legislação deuteronomista (Dt 21,1-2.6-7) a respeito do delito praticado na planície e debitado à vila mais próxima:

Com essa responsabilidade "horizontal" entrelaça-se a "vertical", de geração, segundo a qual os filhos são responsáveis pelas culpas dos pais "até a sétima geração". É evidente a ligação dessa responsabilidade de geração com as normas de transmissão hereditária da propriedade: primeiro de maneira automática (privilegiando o primogênito), depois com a possibilidade de escolha (as várias bênçãos patriarcais no leito de morte), mas sempre de pai para filho. Ao assumir o benefício da herança patrimonial, o filho assumia também o ônus de eventuais pendências não somente financeiras, mas também penais. As duas formas de responsabilidade corporativa entram em crise progressivamente a partir

${ }^{13}$ LIVERANI, M., Para além da Bíblia, p. 259-260. 
de mudanças socioeconômicas de longo prazo; mas o desastre nacional e o exílio acelerarão a crise. $\mathrm{O}$ indivíduo não se encontrava mais inserido numa estrutura política e num tecido social que o protegiam, em cujo âmbito acontecia uma regular transmissão de propriedade da qual tirava o sustento. Tal situação resultava na formulação de um quadro de referência pessoal, em que o indivíduo assumia todas as responsabilidades, mas não pretendia assumir as alheias - conforme os esclarecedores textos de Jeremias $(31,29-30)$ e Ezequiel $(14,13-16) .{ }^{14}$

A linguagem teológica de Baldad está a serviço da defesa de sua doutrina. Por isso, ao culpabilizar um pai pela morte de seus filhos e filhas, não se sente mal. Estamos diante de uma teologia que faz apologia da morte e que não sai em defesa da vida. Alonso Schöke ${ }^{15}$ salienta que as palavras teológicas de Baldad devem ter soado com brutalidade aos ouvidos de Jó. Baldad não tem interesse algum em examinar os detalhes do caso dele e muito menos está disposto a questionar a justiça de Deus. Se Jó havia negado a revelação por meio de sonhos de Elifaz, agora ele rejeita a tradição porque ela também não respondia com ponderação a nada. Se Jó quisesse atender a solução prescrita por Baldad a partir da tradição, ele deveria se esquecer do sofrimento que pesava cotidianamente sobre ele e alterar sua fisionomia, ou seja, transparecer em seu rosto uma alegria incontida (Jó 9,27), sugerindo a Jó, nesse caso, um falso conformismo. Todavia, Jó não compactuava com a hipocrisia e uma mentira. Ele estava plenamente convencido de que seu comportamento não mudaria o tratamento de Deus para com ele (Jó 9,28b).

A teologia de Baldad é perigosa porque produz a exclusão do humano. Não se trata de uma teologia que procura os caminhos da solidariedade e da fraternidade. Ao contrário, ao reduzir o ser humano à condição de verme "Se nem mesmo a lua é brilhante, nem as estrelas são puras, aos olhos dele, quanto menos o homem, esse verme; o ser humano, essa larva" (Jó 25,5-6) -, ele rompe os laços de solidariedade e dá margem para a construção de uma sociedade onde não cabem todas as pessoas. Ao desumanizar o ser humano e retirar dele a sua dignidade, Baldad está legitimando uma teologia produtora de antivida, ou seja, uma teologia que produz exclusão. Poderia, de fato, ser mais fácil olhar para o outro ser humano além de nós como se ele fosse um verme. Através dessa percepção naturalizaríamos os processos de desumanização e,

\footnotetext{
${ }^{14}$ ROSSI, L. A., A origem do sofrimento do pobre, p. 47.

${ }^{15}$ ALONSO SCHÖKEL, L. A.; SICRE DIAZ, J. L. S., Job.
} 
nesse caso, consideraríamos natural, e até mesmo necessário, desviar os olhos, os passos e as mãos daquele que sofre porque se tornou vítima das forças sociais, econômicas, políticas e religiosas que desestruturam o cotidiano, transformando-o no caos primordial.

Nem tudo está perdido na teologia de Baldad. Ela pode, ao menos, estimular a reflexão a respeito de muitas perguntas atuais, tais como: 1) seria possível pensar numa teologia que não protege o ser humano? 2) qual a utilidade de uma teologia que não assume a linguagem da vítima? 3) para que serve um sistema teológico que não consegue levar as pessoas a se interessarem umas pelas outras e a caminhar ao encontro delas, principalmente dos mais vulneráveis?

De acordo com Rossi,

Baldad seria o representante de uma teologia que perdeu sua referência e missão no mundo ao desviar seus olhos dos objetivos e ao negar a vida como ato primeiro e necessário para a sobrevivência da própria teologia. Em uma cosmovisão em que o direito à vida é mais importante que o direito à propriedade, o clamor do pobre é uma exigência que requer resposta, não como ato de generosidade adicional ou legal, mas sim como resposta da própria justiça. Ele está convencido de sua teologia e dela não deseja abrir mão. Ele se acha possuidor de toda a verdade, simbolizando, assim, a maneira mais imatura que as pessoas religiosas têm ao quererem demonstrar que conhecem a verdade. Mas o problema não se encontra somente em Baldad; muitos de nós vivemos dessa forma. Apropriamo-nos de nossa "verdade" muito cedo na vida e não queremos ser incomodados com nenhuma outra evidência. ${ }^{16}$

O famoso ensino de Baldad pode ser assim resumido: quando se faz alguma coisa errada, certamente virá a punição. A confirmação de sua tese é baseada em uma versão da lei natural, isto é, sem água, as plantas não crescem. Portanto, de forma semelhante às leis naturais, quando alguém pecar ele será punido, mas quando for bom, será recompensado. Apressadamente poderíamos dizer que esse discurso faz sentido. Contudo, não são as leis naturais que governam o relacionamento das pessoas com Deus. Baldad poderia ser considerado um dogmático por excelência e, em linguagem contemporânea, poderíamos denominá-lo de "fundamentalista", isto é, ele se recusa a repensar a tradição - que para ele é verdadeira e única.

${ }^{16}$ ROSSI, L. A. S., A origem do sofrimento do pobre, p. 47. 
Ternay assim resume o discurso de Baldad:

A audácia de Baldad foi ainda maior. Ele pergunta: "Deus falsearia o direito e a justiça, a própria justiça dele" $(8,2)$. Assim, Baldad obrigou praticamente Jó a responder que o processo com Deus é um processo impossível e mesmo irrealizável. Como o homem pode ter razão diante de Deus ou ainda mais contra Deus? O debate entre o homem e Deus é radicalmente desequilibrado. ${ }^{17}$

\section{Teologia como defesa de privilégios}

O terceiro amigo a entrar em cena é conhecido pelo nome de Sofar e suas palavras teológicas deixam transparecer que a religião existe para proteger os privilegiados. Ele anuncia a sabedoria como solução e quem não a desejaria? Porém a sabedoria em questão não estava ao alcance de todos; somente uns poucos privilegiados poderiam dela usufruir e, formando um grupo secreto, mantinham em segredo o dom recebido, isto é, a sabedoria era somente daqueles considerados eruditos e sábios.

E porque a sabedoria era cativa de seus desejos, mantinham o homem e mulher do povo afastado dela em completa ignorância para que se tornassem cada vez mais, totalmente dependentes deles, os sábios, assim como para que a fama de sábios pudesse ser cada vez maior. Todavia, estamos diante de um tipo de sabedoria que não liberta e, na verdade, aprisiona. ${ }^{18}$

O povo, sem conhecimento, é presa fácil para a manipulação. Usa-se a teologia como negação do diálogo e, mais do que isso, para cassar a palavra dos pobres; negando o encontro de todos os homens e de todas as mulheres para a tarefa comum de interpretar, construir e reconstruir criativamente seu mundo. Freire nos ajuda a entender essa relação por meio de um conjunto de perguntas:

Como posso dialogar, se alieno a ignorância, isto é, se a vejo sempre no outro, nunca em mim? Como posso dialogar, se me admito como um homem diferente, virtuoso por herança, diante dos outros, meros "isto", em quem não reconheço outros eus? Como posso dialogar, se me sinto participante de um gueto de homens puros, donos da verdade e do saber, para quem todos os que estão fora são "essa gente"? Como posso dialogar, se parto de que a pronúncia do mundo é tarefa de homens seletos e que

${ }^{17}$ TERNAY, H., Livro de Jó, p. 98.

${ }^{18}$ ROSSI, L. A. S., A origem do sofrimento do pobre. 
a presença das massas na história é sinal de sua deterioração que devo evitar? Como posso dialogar, se me fecho à contribuição dos outros, que jamais reconheço, e até me sinto ofendido com ela? ${ }^{19}$

A ausência do diálogo revela uma sociedade fundamentada no monólogo. Todavia, a teologia exige o diálogo, o encontro e não a cassação da palavra. Rossi enfatiza que sem diálogo não há teologia e que a autossuficiência e a autoreferência é incompatível com o diálogo teológico. E acrescenta:

Muitas vezes nos sujeitamos ou ainda sujeitamos as pessoas com um tipo de discurso teológico baseado no "eu penso por você". No livro 1984, Orwell interpreta muito bem essa realidade. Na obra, o Estado controlava o pensamento dos cidadãos, entre muitos outros meios, pela manipulação da língua. Os especialistas do Ministério da Verdade criaram a Novilíngua, uma língua ainda em construção, que quando estivesse finalmente completa impediria a expressão de qualquer opinião contrária ao regime. Uma das mais curiosas palavras da Novilíngua é a palavra duplipensar, que correspondia a um conceito segundo o qual era possível ao indivíduo conviver simultaneamente com duas crenças diametralmente opostas e aceitar ambas. O objetivo da implantação do novo idioma era reduzir o vocabulário ao extremo para diminuir a capacidade de pensamento, tornando as pessoas vulneráveis ao Partido. A eliminação de sinônimos e a fusão de palavras tornavam a relativização impossível. As novas palavras que eram criadas tinham a intenção de tornar várias outras obsoletas. A cada edição do dicionário de Novilíngua menos vocabulários estavam presentes. Assim, o duplipensamento ficava mais fácil de ser absorvido e as pessoas, de serem controladas. ${ }^{20}$

Toda realidade é passível de transformação e, por isso, é dinâmica. Somente quando a realidade e a sociedade são compreendidas como sagradas é que sua ordem não pode ser alterada, questionada ou sequer modificada. Jó, a personificação daquele que é derrotado por forças exteriores, é visto como uma verdadeira ameaça. O desafio dele é o de romper com o marco de referência da sociedade bem como da teologia oficial que se cristalizaram, assim como romper com os valores preestabelecidos para uma verdadeira reformulação de sua maneira de se situar no mundo. O discurso teológico de Sofar demonstra o caráter patológico de sua teologia, uma teologia que

\footnotetext{
${ }^{19}$ FREIRE, P., Pedagogia do Oprimido, p. 80.

${ }^{20}$ ROSSI, L. A. S., A origem do sofrimento do pobre, p. 49.
} 
desumaniza os que viviam na periferia do mundo. Na representação imagética dos discursos de Sofar podemos enxergar dois lados em confronto: de um lado Sofar, como representante legítimo daqueles que tudo sabem, tudo ensinam e tudo interpretam, e do outro lado, os que vivem na periferia - representados por Jó - que nada sabem, nada produzem e tudo recebem. Contudo, toda teologia eivada de conotações patológicas, nega a vocação ontológica de todo ser humano, isto é, nega seu direito a ser participante e não mero expectador da história; que nega a autonomia para que viva sempre na menoridade. Uma teologia patológica que fala de liberdade com o objetivo de sufocar o discurso que vem da periferia. Rossi afirma que "Muitas vezes a utilização do controle do saber e da informação é um dos melhores instrumentos que os líderes religiosos incorporam a fim de manipular seu grupo religioso". ${ }^{21}$

A resposta de Sofar ao problema de Jó pode ser assim descrito: Jó deveria de alguma maneira pertencer a esse grupo religioso altamente privilegiado pois, fazendo assim, até seus sofrimentos acabariam: "se ensinasse a você os segredos da sabedoria, que são tão difíceis de entender, então você saberia que Deus perdoa parte de sua culpa" (Jó 11,6). Todavia Jó novamente haverá de recusar a proposta de Sofar usando de ironia fina: "Realmente sois a voz do povo" (Jó 12,1). Alonso Schökel sugere que Sofar não consegue compreender as palavras de Jó como expressão da dor e da amargura. ${ }^{22}$ Suas observações são de ordem doutrinal que, por isso mesmo, não compreende a dor humana e prefere permanecer com a doutrina. De tão sábio ele não consegue visualizar o conceito de justiça como desenvolvido pelos profetas de Israel. Nos profetas o destino dos pobres é a chave para se compreender a justiça de uma sociedade. Até mesmo as leis a respeito da terra e da colheita eram elaboradas para a proteção dos pobres (Lv 25; Dt 23,25-26). Tipicamente, no Antigo Testamento, encontramos a tríade social, ou seja, o órfão, a viúva e o estrangeiro. Não há espaço aqui para a naturalização da violência. Os seus inimigos são os poderosos movidos pela ganância. E nos Salmos lemos que Javé demonstra sua justiça ao defender os pobres da ganância dos poderosos (S1 82,3-4).

Rossi, a respeito da cosmovisão dos israelitas, afirma:

Percebia-se uma inimizade potencial e muito perigosa dos ricos em relação aos pobres. Javé, nessa situação de conflito, por não fazer acepção de pessoas, toma partido dos pobres (Deuteronômio 10,16-19). Não

${ }^{21}$ ROSSI, L. A. S., A origem do sofrimento do pobre, p. 49.

${ }^{22}$ SCHOKEL, L. A.; DIAZ, J. L. S., Job. 
por acaso, Jó faz uso do conceito de Goel: "Eu sei que o meu redentor [goel] está vivo, e que no fim se levantará acima do pó" (Jó 19,25). Mas qual o significado de goel/redentor? O termo é usado no hebraico bíblico principalmente no âmbito legal. Segundo o Código de Santidade (Levítico 17-26), a terra deveria ser distribuída perpetuamente entre as famílias de Israel. Mas se um homem de Israel incorresse em dívidas que não pudesse pagar e se lhe tomassem a terra para cobrir essa dívida, o parente mais próximo se convertia em goel/redentor, com a responsabilidade de redimir a terra, pagando-a para que não caísse em mãos estranhas à família. No livro de Rute é narrado um caso em que essa lei é aplicada, quando Booz redime a dívida de seu parente Elimelec, que havia morrido. Deste contexto legal a palavra goel passa à linguagem da oração em um sentido de libertação. Uma libertação que o suplicante espera da intervenção de Deus diante de seu inimigo (Salmos 69,18; 78,35). Várias vezes o temor redentor é aplicado a Javé por sua façanha de libertar Israel da escravidão egípcia. O segundo Isaías aplica o epíteto redentor várias vezes a Javé (Isaías 43,14; 44,6; 47,4). Goel, a partir daí, torna-se o defensor em justiça, aquele que reivindica o direito dos oprimidos (Provérbios 23,10-11). $\mathrm{O}$ uso da palavra por parte de Jó parece indicar que ele fazia parte do grupo dos camponeses que praticavam estes costumes. Eles procuravam se ajudar comunitariamente. Contudo, este estilo de vida estava perdendo a sua força. A injustiça crescia, a pobreza avançava, eles não podiam mais manter estas práticas e esperar que, por meio delas, fossem salvos da miséria. ${ }^{23}$

O resumo apresentado por Ternay quanto ao discurso de Sofar é assim descrito:

Sofar atacou Jó ainda mais brutalmente. Ele explicitou uma acusação que ficara velada nos discursos anteriores: Jó cometeu uma falta. Jó é um pecador que não tem direito nem motivo para se queixar de seu sofrimento (...) Não se pode pedir satisfação a Deus de nenhum dos seus atos. Deus faz o que quer, quando quer, a quem quer. Isso fecha toda a discussão. Só resta calar-se. ${ }^{24}$

\section{A surdez da teologia}

O quarto amigo de Jó a aparecer na narrativa é Eliú. Sua teologia não é diferente das outras três. Trata-se de uma teologia que não protege o ser humano;

${ }^{23}$ ROSSI, L. A. S., A origem do sofrimento do pobre, p. 51.

${ }^{24}$ TERNAY, H., O livro de Jó, p. 90. 
ao contrário, prejudica-o. Para Eliú, Deus não somente envia revelações em sonhos noturnos para fazê-lo sentir-se mortal, mas se serve também do sofrimento físico para corrigir aquele que se esquece de sua finitude, ou seja, seus limites. ${ }^{25} \mathrm{~A}$ forte expressão que Eliú deseja colocar nos lábios de Jó - “Eu tinha pecado e violado o direito" (Jó 33,27) - revela cabalmente uma teologia envelhecida. A ligação apressada da doença com o pecado é uma antecipação do que ele deseja comunicar e que Jó exaustivamente e enfadonhamente escutou dos outros três amigos.

Jó poderia voltar à sua posição original, mas, para isso, precisaria confessar seus pecados e arrepender-se deles. Estamos às voltas com o conselho convencional da tradição religiosa que estabelece a justiça de Deus e a injustiça humana quando acontecem casos de conflito. Assim como os demais amigos, Eliú não está interessado em investigar o passado de Jó. Eles partem do princípio de que Jó é pecador, ou seja, quando chegaram para visitar o amigo, o veredito já estava dado. Para ele, está claro que Jó é identificado com os homens iníquos e rebeldes que desprezam o governo de Deus, alguém perigoso que deve ser excluído do círculo de amizade, alguém que semeia dúvida e multiplica protestos. Se tudo já está definido e ajustado, se a teologia dos amigos é perfeita e não admite erros ou lacunas, ela também não tolerará qualquer tipo de questionamento. Nesse tipo de teologia não há espaço para a dúvida, pois se apresenta sempre como absoluta e perfeita. A constatação de Rossi é pertinente:

Eliú indica que a boa teologia é aquela seguida sem questionamentos. Portanto, o veredicto dos sábios (Jó 33,33) não poderia ser outro: Jó fala sem conhecimento. Eliú gaba-se de proferir palavras de conhecimento - "Falo de coração sincero, e os meus lábios falarão claramente" (Jó 33,3) - e o próprio Elifaz anteriormente insinuava que Jó somente respondia com "doutrinas falsas" (Jó 15,2). O que acontece é que Jó - através de sua experiência semeava a dúvida no meio de sábios seguros demais da solidez da sua teologia. Jó estava abalando as certezas dos teólogos do sistema estabelecido. Estes se recusavam a se deixar questionar pelos desafios da vida. Na verdade, a vida pouco lhes importava, conquanto pudessem ser iluminados pela teologia que sustentava sua indiferença diante da dor daqueles que sofriam. Contudo, teologia alguma pode nos tornar indiferentes diante da dor de homens e mulheres, sob o risco de se tornar uma antiteologia. ${ }^{26}$

${ }^{25}$ TERNAY, H., O livro de Jó.

${ }^{26}$ ROSSI, L. A. S., A origem do sofrimento do pobre, p. 52. 
Há em Eliú um atrevimento teológico que, até mesmo, nega a tradição de que Deus ouve a oração daqueles que clamam. Sem escrúpulos ele afirma que os oprimidos não são ouvidos porque não dirigem os seus gritos ao Deus que os criou. Trata-se de uma teologia cínica e indiferente ao sofrimento dos mais vulneráveis. Ao retratar Jó como insensato, ele alça Jó como representante de todas as pessoas que desqualificadas, desvalorizadas e desumanizadas por uma teologia que, ao invés de libertar o ser humano, aprisiona-o. A base do argumento teológico de Eliú chama atenção porque faz referência a uma possível ação pedagógica de Deus a partir do sofrimento. A dor, sim, é enviada por Deus, mas com um objetivo, isto é, chamar a atenção do pecador para que se converta e, assim, possa desfrutar de bem-estar. Aos olhos de Eliú, a experiência de Jó se encaixa perfeitamente bem em suas palavras definidoras de teologia. Jó se converteu em um pecador renitente ao recusar o chamado de atenção com o qual Deus pretendia salvá-lo de sua má conduta. Deus, como a autoridade suprema, faz somente o bem, e se castiga é porque necessariamente deve haver um motivo. Deus jamais erra. Assim, se Deus envia a aflição é para conhecer a maldade do coração humano e, dessa forma, corrigir aqueles que se perderam pelo caminho, a fim de que o pecador se converta de sua iniquidade.

Eliú, com toda a segurança dada por sua teologia, permite-se dizer a Jó que o sofrimento dele deve ser visto como uma advertência de um Deus bondoso e que é generoso em sua pedagogia. Enquanto os três amigos de Jó afirmavam que o sofrimento era simplesmente o castigo do pecado, Eliú insiste em mostrar e defender o caráter disciplinar e educador do sofrimento. Posicionamento ratificado por Pixley ao examinar Jó 36,5-12 e chegar à conclusão que "a dor é enviada por Deus para chamar a atenção do pecador a fim de que se converta e goze de bem-estar". ${ }^{27}$

\section{Conclusão}

Os três primeiros amigos de Jó falavam que Deus fazia os injustos sofrerem e que a doença era um sinal da injustiça deles. Não havia escapatória diante desse fato teológico. Eliú, o quarto amigo, apresentará um Deus que usa um tipo especial de pedagogia do sofrimento como forma de salvar as pessoas. Deus seria o autor do sofrimento do justo. Mas a quem interessa uma teologia que não vê o sofrimento do outro como uma possibilidade de

${ }^{27}$ PIXLEY, J., El libro de Job, p. 184. 
solidariedade e de fraternidade? A resposta poderia ser que interessa aos grupos políticos, religiosos, econômicos, etc., que desejam pessoas diante de si mansas, honestas, bem-comportadas, respeitosas, educadas, religiosas e que se submetam a tudo e a todos, sem se revoltarem contra a injustiça e, principalmente, sem exigiram os próprios direitos. No entanto, o problema com essa linha de raciocínio é que ela não ajuda a quem sofre e muito menos explica seu sofrimento e, principalmente, não cria laços de solidariedade. A preocupação primeira é a defesa de um sistema teológico que utiliza palavras e ideias de conotação religiosa para transformar o mal em bem e a dor em privilégio. Trata-se, portanto, de uma teologia vazia; uma teologia que mostrava que os amigos acreditavam piamente no discurso teológico oficial e menos na força da solidariedade e da consolação.

A teologia da retribuição estava assumindo a sua forma e assim permanecerá durante o desenrolar de todo o livro de Jó. O ser humano pode, sim, ser conduzido a agir por interesse: se ele faz o bem, recebe a felicidade; se pratica o mal, recebe a infelicidade. A vida de fé está a um passo de se transformar em uma relação comercial. A fé pode ser vista a partir de uma prateleira de supermercado, ou seja, Deus se apresentaria como um negociante. A consagrada expressão brasileira do "toma lá, dá cá" se encaixaria perfeitamente nessa situação.

Imageticamente, temos de um lado a letra fria da ortodoxia e, de outro, a experiência cotidiana da dor, da calamidade e da derrota. Jó, a partir de sua experiência paradigmática, quer enfatizar que os seus amigos não têm o que falar porque não estão passando pela duríssima experiência de sofrimento, pela qual ele, Jó, está passando. Se ele está gritando de dor física, mental e moral, é porque está sofrendo intensamente. Contra a teologia da retribuição ele tem um único argumento: sua experiência pessoal e sua observação da história, na qual a injustiça permanece impune. Sua observação e intuição são corretas: existem somente homens e mulheres situados no espaço e no tempo, no sentido de que vivem em uma época precisa, em um contexto social, cultural e econômico preciso. Consequentemente, a teologia para ser válida e eficaz deveria levar em consideração a vocação ontológica do ser humano vocação para ser sujeito - e as condições nas quais eles vivem. Mais do que isso, Jó, em sua teologia, procura mostrar que, para ser realmente válido, o discurso sobre Deus deve ajudar o ser humano a chegar a ser sujeito.

Todos os amigos, sem exceção, representam perfeitamente o modo mais comum de mascarar a fé bíblica por meio da teologia oficial, revestida de 
ortodoxia, a fim de explicar a realidade. Por isso todos eles, sobremaneira incomodados com os discursos teológicos de Jó, feitos desde a periferia do sofrimento, convertem-se de consoladores em teólogos rabugentos e saem da narrativa menores do que quando entraram.

\section{Referências bibliográficas}

ALONSO SCHÖKEL, L. S; SICRE DIAZ, J. L. D. Job. Comentario teológico y literario. Madrid: Cristiandad, 2002.

FREIRE, P. Pedagogia do Oprimido. São Paulo: Paz e terra, 1988.

LIVERANI, M. Para além da Bíblia. História antiga de Israel. São Paulo: Paulus, 2008.

PIXLEY, J. EI libro de Job. Costa Rica: Ediciones Sebila, 1982.

POPE, M. Job. Introduction, Translation and Notes. New York: Doubleday, 1973.

ROSSI, L. A. S. A falsa religião e a amizade enganadora. São Paulo: Paulus, 2005.

ROSSI, L. A. S. A origem do sofrimento do pobre. São Paulo: Paulus, 2017. SCHONBERGER, L. S. Um caminho através do sofrimento. O livro de Jó. São Paulo: Paulinas, 2011.

TERNAY, H. O livro de Jó. Da provação à conversão, um longo processo. Petrópolis: Vozes, 2001.

Luiz Alexandre Solano Rossi Doutor em Ciências da Religião pela Universidade Metodista de São Paulo Docente na Pontifícia Universidade Católica do Paraná Curitiba / PR - Brasil E-mail: luizalexandrerossi@yahoo.com.br

Recebido em: 09/01/20

Aprovado em: 01/06/20 